\title{
Aksjologiczne podstawy ładu politycznego w dobie globalizacji
}

Nauka społeczna interesuje się człowiekiem w jego powiązaniu ze złożoną siecią relacji, charakterystyczną dla współczesnych społeczeństw stwierdza Jan Paweł II w encyklice Centesimus annus ${ }^{1}$. Aby człowiek mógł w sposób możliwie pełny odkryć własną tożsamość, niezbędne jest $\mathrm{w}$ tym procesie uwzględnienie dorobku nauk przyrodniczych, filozofii oraz teologii. Stąd nauka społeczna Kościoła, a w niej tekst doniosłej i bogatej merytorycznie encykliki wydanej w setną rocznicę ukazania się dokumentu Leona xiII o kwestii robotniczej, odgrywa istotną rolę w kształtowaniu personalistycznego ładu społecznego.

Przedmiotem analizy uczonych wspierających nauczanie Kościoła w tym obszarze są warunki umożliwiające pełny rozwój osoby ludzkiej. Rozwój ten może być zapewniony jedynie we wspólnocie innych osób w społeczeństwie wyposażonym we wszelakie instrumenty wszechstronnego rozwoju intelektualnego, moralnego i fizycznego. Przestrzenią egzystencji człowieka jest więc społeczeństwo jako całość, wraz z jego subsystemami: gospodarczym, kulturowym i politycznym. Tym ostatnim zajmiemy się w kontekście jego aksjologicznych podstaw.

Interesować nas będą uniwersalne normy, zasady i wartości nieodzowne dla polityki wykraczającej poza granice państw narodowych, której celem jest kształtowanie ładu społeczno-gospodarczego o zasięgu międzynarodowym. Celem niniejszego artykułu jest więc próba ukazania znaczenia ładu politycznego w dobie globalizacji, którego podstawą są uniwersalne wartości. W analizie tej będziemy opierali się głównie na literaturze Lubelskiej Szkoły Katolickiej Nauki Społecznej,

\footnotetext{
1 Zob. CA 54 .
} 
ze szczególnym uwzględnieniem dorobku jej wybitnego przedstawiciela ks. prof. Franciszka Janusza Mazurka (1933-2009), filozofa społecznego, socjologa i teoretyka praw człowieka. Uczony ten właśnie problematyce wartości w polityce poświęcił ostatnie lata swoich intensywnych badań.

\section{Zasada godności osoby ludzkiej podstawą demokracji integralnej}

Metodologia katolickiej nauki społecznej sytuuje politykę w pozycji integralnej z innymi obszarami funkcjonowania społeczeństwa. Podejście to koresponduje z Oswalda von Nell-Breuninga koncepcją ładu społeczno-gospodarczego, gdzie zasadnicze znaczenie dla tego ładu ma relacja trzech podstawowych obszarów, nazywanych ogólnie społeczeństwem, polityką i gospodarką (sociologicum, politicum, oeconomicum). Dla niemieckiego uczonego najszerszą kategorię stanowi społeczeństwo, które jest nadrzędne wobec państwa i gospodarki, przy czym - o ile społeczeństwo i państwo stanowią pewnego rodzaju jedność, bo scala je prawo i władza, o tyle gospodarka pełni jedynie funkcję służebną wobec społeczeństwa². Taką służebną rolę należy przypisać również państwu, bowiem „jedyną racją istnienia władzy państwowej jest dobro wspólne"3.

Nauczycielski Urząd Kościoła nie zajmuje się polityką w sensie praktycznych i doraźnych rozwiązań, nie analizuje programów partii politycznych i nie wskazuje na jakikolwiek model rządzenia jako jedynie słuszny. W centrum jego zainteresowania znajdują się wartości, których uwzględnianie traktuje on jako niezbędny warunek właściwej i skutecznej polityki. Podstawowa więc teza, która będzie dalej uzasadniana, brzmi: właściwy model polityki to ten, który respektuje podstawowe wartości. Pierwszą z nich jest godność bytu ludzkiego, następnie wolności podstawowe i prawa człowieka, równość, solidarność, demokracja, państwo prawa, sprawiedliwość społeczna, życie ludzkie i jego poszanowanie od poczęcia do śmierci, wolny rozwój osobowościowy,

\footnotetext{
S. Fel, Oswalda von Nell-Breuninga koncepcja ładu społeczno-gospodarczego, Lublin 2007 , s. $87-88$.

3 F. J. Mazurek, Prawo naturalne podstawą stosunków społecznych, „Roczniki Filozoficzne" 21 (1973), z. 2, s. 57.
} 
dialog, pokój, praca, kultura, środowisko naturalne, postęp naukowo-techniczny, rozwój społeczno-gospodarczy ${ }^{4}$. Wśród wymienionych wartości godność osoby ludzkiej uznawana jest za normę. W obszarze polityki godność ta jako wartość najwyższa „znaczy, że człowiek nie jest dla państwa, lecz państwo jest dla człowieka, że człowiek nie jest dla ustroju społeczno-politycznego, nawet wówczas, gdy jest to ustrój demokratycznego państwa prawa"s. Na tej właśnie podstawie Mazurek uważa, że nie zasady demokratycznego państwa prawa, lecz godność osoby ludzkiej powinna być najwyższą zasadą konstytucji ${ }^{6}$. Nie znaczy to, że neguje on samą demokrację, przeciwnie, opowiada się za demokracją integralną, to znaczy taką, która nie ogranicza się jedynie do dziedziny politycznej - tak zredukowaną nazywa demokracją kadłubową. Uważa natomiast, że powinna ona opierać się na zasadzie godności osoby ludzkiej oraz zasadzie integralnie rozumianych praw człowieka (wolnościowych, społecznych, gospodarczych, kulturalnych i solidarnościowych). Demokracja integralna obejmuje więc też dziedzinę gospodarczą. Ilustracją demokracji kadłubowej jest dla niego sytuacja przedsiębiorstw państwowych i prywatnych: „Przedsiębiorstwa państwowe i prywatne funkcjonują w dużym stopniu tak, jak funkcjonowała monarchia absolutna w XvIII wieku. Istniejące formy demokracji politycznej są kadłubowe, gdyż nie obejmują życia gospodarczego. Prawo do partycypacji to prawo ludzi pracy do podmiotowości także w dziedzinie gospodarczej. Prawo do partycypacji jest niezależne od tego, czy przedsiębiorstwa są państwowe czy prywatne. Demokracja polityczna domaga się uzupełnienia przez demokrację gospodarczą"7.

Stanowisko to zbieżne jest $\mathrm{z}$ rozumieniem demokracji przez Franza Klübera, który jako podstawę prawidłowego rozumienia demokracji gospodarczej wskazuje analogię z demokracją polityczną jako formą ustrojową państwa. Koncepcja ta uznaje za wymóg sprawiedliwości walkę z wykluczeniem obywateli z życia ekonomicznego, politycznego

4 Tenże, Wartości akceptowane w Unii Europejskiej, „Summarium” 28-29 (1999-200o), S. $12-13$.

5 Tenże, Godność osoby ludzkiej jako norma, „Społeczeństwo. Studia. Prace badawcze. Dokumenty z zakresu nauki społecznej Kościoła” 4 (1995), s. 765.

6 Tamże.

7 Tenże, Integralne rozumienie praw człowieka podstawa personalistycznego porządku społecznego, „Zeszyty Naukowe KUL” 39 (1996), nr 1-2, s. 71. 
i kulturalnego. Demokratyzacja życia gospodarczego oznacza tu rozszerzenie demokracji formalnej do demokracji realnej.

Punktem wyjścia zdrowej demokracji jest przyjęcie właściwej koncepcji człowieka wraz ze wszystkimi jej prawno-naturalnymi konsekwencjami. Demokracja integralna pojmowana jest jako styl życia, a jej charakterystycznymi cechami są: uznawanie obiektywnych i uniwersalnych norm moralnych, przestrzeganie wszystkich praw człowieka oraz faktyczny trójpodział władzy ${ }^{9}$. Decentralizacja władzy i jej podział na ustawodawczą, wykonawczą i sądowniczą oraz demokratyzacja życia społeczno-politycznego i gospodarczego są wymogiem ciągle aktualnej i coraz powszechniej uznawanej zasady pomocniczości.

Godziwość ustroju demokratycznego zależy przede wszystkim od dwóch czynników: przyjętej odpowiedniej antropologii oraz praworządności. Takie stanowisko wyraził Jan Paweł II w Centesimus annus: „Autentyczna demokracja możliwa jest tylko w Państwie prawnym i w oparciu o poprawną koncepcję osoby ludzkiej”'10. Podejście to przyjęli nie tylko przedstawiciele Lubelskiej Szkoły Katolickiej Nauki Społecznej. Również ojcowie niemieckiej społecznej gospodarki rynkowej, Alfred Müller-Armack, Alexander Rüstow, Wilhelm Röpke, oparli ją na fundamencie aksjomatu: ludzka natura jest miarą prawa i porządku. Elmar Nass z Uniwersytetu w Bochum stanowisko to nazywa konstytucją konstytucji i uważa, że powinno ono „chronić demokratyczne państwo prawa przed zakusami ideologii, które pod płaszczykiem pięknych słów podsuwają jako demokratyczne, ludzkie lub etyczne to, co w rzeczywistości jest totalitarne i nieludzkie"11. Z kolei Müller-Armack uważa, że za ostateczne kryterium porządku nie można uznać takiego celu jak władza, prawo,

${ }^{8}$ S. Fel, J. Kupny, Humanizacja życia gospodarczego. Wybrane zagadnienia $z$ etyki gospodarczej, Lublin 2000, s. 92-93; zob. F. J. Mazurek, Kryteria aksjologiczno-personalistycznej oceny wykluczeń w różnych dziedzinach i wymiarach, w: Kultura. Media. Społeczeństwo. Ksiega Jubileuszowa ku czci Ojca Profesora Leona Dyczewskiego ofmconv, red. D. Wadowski, Lublin 2007, s. 633-646.

9 F. J. Mazurek, Katolicka nauka społeczna - status metodologiczny i główne obszary problemowe, w: Katolicka nauka społeczna. Podstawowe zagadnienia z życia społecznego i politycznego, red. S. Fel, J. Kupny, Katowice 2007, s. 29.

${ }^{10}$ CA 46; zob. Papieska Rada „Iustitia et Pax”, Kompendium nauki społecznej Kościoła, Kielce 2005, n. 406.

${ }^{11}$ E. Nass, Państwo prawa i państwo socjalne w ujęciu chrześcijańskim, w: Katolicka nauka społeczna..., s. 148. 
wolność, demokracja, dyktatura, lecz tylko to jedno - humanitas ${ }^{12}$. Pod tym pojęciem rozumie on człowieczeństwo; ucieleśnienie tego wszystkiego, co odnosi się do pogłębionego rozumienia człowieka jako osoby, $\mathrm{z}$ wyeksponowaniem jej istnienia i spełnienia.

Wśród licznych czynników decydujących o właściwym funkcjonowaniu państwa należy wskazać na trzy kluczowe: instytucja prawa, demokracja i moralna dojrzałość obywateli. Osłoną zewnętrzną wolności społecznej - stwierdza Mazurek - jest instytucja prawa. Ma on tu na myśli głównie prawa wolnościowe: prawo do wolności słowa, religii, sumienia, zrzeszania się, emigracji, imigracji. Aby prawa te były zagwarantowane obywatelom, niezbędna jest instytucja państwa. Stwierdza on wręcz, że bez państwa wolność społeczna byłaby niemożliwa, gdyż realizuje się ona $\mathrm{w}$ państwie i przez państwo ${ }^{13}$. Mamy wówczas do czynienia z tzw. państwem wolnościowym. Gwarantuje ono wolność społeczną, ale - by ją zapewniać - musi też ją ograniczać. Jest to niezbędne w tym celu, by odpowiedni jej zakres zagwarantować wszystkim. Ograniczenie wolności celem jej zagwarantowania dla wszystkich jest kryterium państwa wolnościowego, czyli demokratycznego ${ }^{14}$. Przeciwieństwem takiego państwa jest państwo totalitarne lub państwo pozbawione ładu; państwo chaosu. Państwo wolnościowe - demokratyczne, bierze odpowiedzialność za wszystkie obszary życia. Przymiotnik „demokratyczne" ma tu podobne znaczenie do tego, którym posłużyliśmy się wyżej w teorii demokracji integralnej. Odpowiedzialność państwa za całokształt egzystencji społeczeństwa oznacza troskę o życie społeczne, gospodarcze i kulturalne ${ }^{15}$, oczywiście z zachowaniem zasady subsydiarności. Demokracja jest więc swoistym upodmiotowieniem społeczeństwa w dziedzinie politycznej oraz upodmiotowieniem ludzi pracy najemnej w dziedzinie gospodarczej.

$\mathrm{Z}$ ustrojem demokratycznym związaliśmy wreszcie problem dojrzałości moralnej obywateli. Amerykański uczony Michael Novak stwierdza, że praw ludzkich nie chroni martwe słowo, lecz moralność, a prawda

${ }_{12}$ A. Müller-Armack, Genealogie der Sozialen Marktwirtschaft. Frühschriften und weiterführende Konzepte. Sozioökonomische Forschungen, t. 1, Bern Paul Haupt Verlag, BernStuttgart 1974, s. 212.

${ }_{13}$ F. J. Mazurek, Wolność i równość społeczna, „Roczniki Nauk Społecznych” 9 (1981), s. 233 .

${ }^{14}$ Tamże, s. 234.

15 Tamże. 
o godności człowieka musi być uznawana, jeśli demokracja nie ma upaść pod wpływem własnej słabości ${ }^{16}$. Novak pisze o trzech obszarach wolności, które - szczególnie w państwach zniewolonych reżimem - stają się szczególnie pożądane przez obywateli: wolność państwa, wolność gospodarki i wolność systemu moralno-kulturalnego. Te trzy wolności w państwie prawa gwarantowane są instytucjonalnie. Same instytucje jednak nie wystarczą, potrzeba moralnych cnót obywateli, które umożliwiają trwanie tych wolności ${ }^{17}$. Wyzwolenie polityczne i gospodarcze prowadzi więc Novaka do idei prymatu moralności w działalności politycznej.

W katolickiej nauce społecznej osadza się działalność polityczną na wartościach. Ujęcie to jest niewątpliwie wyrazem sprzeciwu wobec indywidualistyczno-liberalnej koncepcji życia społeczno-politycznego. Niklas Luhmann, jeden z teoretyków aksjologicznej neutralności społeczeństwa nowoczesnego, zdaje się podważać omawiane tu humanistyczne ujęcie ładu politycznego, gdy stwierdza, że takie wartości podstawowe, jak godność człowieka, wolność, równość, solidarność, sprawiedliwość, przestają już być wystarczającym kierunkowskazem działania politycznego. Zaznacza on, że wprawdzie nadal stanowią one niekwestionowaną podstawę konsensu, reprezentują znaczenia, na które powołuje się polityka wobec społeczeństwa, $z$ drugiej jednak strony z trudem mogą służyć za miernik politycznych sukcesów i porażek, są mało przydatne do oceny osiągnięć i zupełnie nieprzydatne dla oceny trudności. „Jako idee regulatywne, nie znajdują zastosowania w świecie praktyki, a w rzeczywistości komunikacji politycznej symbolizują $\mathrm{w}$ równej mierze dobre zamiary i złe doświadczenia: fundamentalne idee rewolucji burżuazyjnej wciąż pozostają nie urzeczywistnione" ${ }^{\prime 18}$. Tymczasem w społeczeństwach nowoczesnych właśnie podstawową zaporą rozwoju człowieka wydaje się zachwiana hierarchia wartości. Mazurek zauważa, że hamulce pełnego rozwoju człowieka inaczej funkcjonują w krajach wysoko uprzemysłowionych i inaczej w krajach Trzeciego Swiata. W pierwszych powodowane są przez przestawienie hierarchii wartości, to jest wysunięcie rzeczy

${ }^{16}$ M. Novak, Liberalizm - sprzymierzeniec czy wróg Kościoła. Nauczanie społeczne Kościoła a instytucje liberalne, tłum. W. Büchner, Poznań 1993, s. 311.

17 Tamże.

${ }^{18}$ N. Luhmann, Teoria polityczna państwa bezpieczeństwa socjalnego, tłum. G. Skąpska, Warszawa 1994, s. 148. 
(kapitału) przed człowieka, techniki przed etykę, wartości materialnych przed duchowe i religijne, a także przez manipulację mentalnością i potrzebami ludzi w środkach masowego przekazu myśli. W drugich zaś powodowane są brakiem żywności, lekarstw, brakiem rozwiniętej sieci szkolnictwa i niesprawiedliwymi strukturami społeczno-gospodarczymi ${ }^{19}$.

\section{Mundializacja}

W ostatnich latach coraz powszechniejsze staje się przekonanie, że aktualnie państwo przestało już być społecznością doskonałą, ponieważ nie jest w stanie stworzyć warunków pełnego rozwoju osobowego swym obywatelom bez podejmowania współpracy z innymi państwami ${ }^{20} . \mathrm{Z}$ coraz większą intensywnością eksploatuje się takie pojęcia, jak: ład międzynarodowy, władza ogólnoświatowa, ochrona środowiska naturalnego w skali globu, sprawiedliwość międzynarodowa i międzypokoleniowa.

Mundializacja to zjawisko dotyczące nie tylko dziedziny gospodarczej, ale także społecznej, kulturalnej, religijnej, prawnej, politycznej i ekologicznej. Terminem tym wyraża się szereg procesów zachodzących w jednostce i społeczeństwie na skutek bogatego spektrum zmian w komunikowaniu się, modzie, używaniu środków i zaspokajaniu potrzeb. Mundializacja (łac. mundus - świat) wiąże się z nową mentalnością ludzi, którzy przestali zawężać świat swoich przeżyć i relacji do najbliższego geograficznie środowiska. Świat ten zaciera granice państw i kultur. Ujawnia się ona w życiu konkretnego człowieka przez produkty, których ten używa, informacje, które otrzymuje i przetwarza, przez problemy bezrobocia i zanieczyszczenie naturalnego środowiska, przez możliwość podróżowania i porozumiewania się z innymi za pomocą telekomunikacji, zwłaszcza Internetu ${ }^{21}$ W tym właśnie wyraża się jej wymiar osobowy. W wymiarze społecznym mieści się zjawisko powstawania choćby pozarządowych organizacji międzynarodowych na rzecz interesów, których powodzenie zależy od współdziałania w skali międzynarodowej, a nawet

\footnotetext{
19 F. J. Mazurek, Prawo do rozwoju, „Roczniki Nauk Społecznych” 11 (1983), s. 223.

${ }^{20}$ Tenże, Problem sprawiedliwości międzynarodowej, „Roczniki Nauk Społecznych” 4 (1976), s. 25.

${ }^{21}$ Tenże, Podstawy moralno-prawne globalizacji gospodarczej, w: Państwo narodowe a proces globalizacji, red. E. Okoń-Horodyńska, Kraków 2000, s. 26.
} 
globalnej. Funkcjonowanie tych organizacji prowadzi do ukształtowania w człowieku świadomości, że jest on członkiem jednej rodziny ludzkiej i właśnie dzięki możliwości wpływania na jej sytuację pozostaje on podobnie jak każdy inny członek tej rodziny - jej podmiotem. Dzięki tego typu organizacjom pozarządowym działalność obywatelska nie jest zamknięta w partiach i wyborach, ale każdy obywatel ma możliwość brania udziału w kształtowaniu lepszego świata, pozostając w miejscu zamieszkania ${ }^{22}$.

Obok zjawiska przenikania się różnych kultur (mundializacja w dziedzinie kulturalnej) dostrzega się też znaczenie dialogu między przywódcami wielkich religii świata (wymiar religijny mundializacji), z kolei o wymiarze gospodarczym mundializacji można mówić choćby w kontekście integracji europejskiej oraz istnienia korporacji międzynarodowych. Te ostatnie wykupują inne korporacje i przejmują władzę w dziedzinie gospodarczej w wymiarze światowym ${ }^{23}$. Już to zjawisko wydaje się wystarczającą podstawą do dyskusji nad potrzebą powołania jakiejś formy władzy ogólnoświatowej. Temat ten jest dość żywotny w katolickiej nauce społecznej już od lat 70. minionego wieku. W tym miejscu nie będziemy go jednak szerzej rozwijać.

W dokumencie Komisji „Iustitia et Pax” Episkopatu Francji O właściwy kształt mundializacji stwierdza się, że chrześcijanie nie powinni odrzucać całościowo mundializacji, ponieważ łączy ona i solidaryzuje ze sobą wszystkich ludzi. Dodaje się przy tym, że „każdy aspekt mundializacji powinien być oceniany według trzech kryteriów: czy na pierwszym planie jest w nim człowiek i jego rozwój?; czy ogarnia wszystkich ludzi?; czy respektuje różnice między nimi?”"24.

Pomijając tu etyczną ocenę zjawiska mundializacji, należy wskazać na jego znaczenie w obszarze rozwiązywania podstawowych problemów o randze światowej. Badania nad polityką i jej znaczeniem dla katolickiej nauki społecznej koncentrują się głównie na rozwiązaniach systemowych o charakterze ponadpaństwowym. Powodem tego może być przekonanie

${ }_{22}$ Tamże, s. 45-46.

${ }^{23}$ Tamże, s. 27.

${ }^{24}$ Komisja „Iustitia et Pax” Episkopatu Francji, O właściwy kształt mundializacji, w: Kościót wobec współczesnych problemów życia gospodarczego. Społeczne dokumenty episkopatów, red. S. Fel, J. Kupny, Lublin 2002, s. 313. 
o współzależności zjawisk społecznych, gospodarczych i politycznych w świecie. Z tego choćby względu, że transnarodowe korporacje przejęły władzę gospodarczą w skali światowej, należy powołać światową władzę polityczną ${ }^{25}$. Stanowisko Franciszka Mazurka w tym względzie, przejawiające się w jego etycznej ocenie zjawiska globalizacji, wydaje się szczególnie trafne, wręcz zbieżne z kryterium antropologicznym postawionym przez papieską komisję. Stwierdza on mianowicie, że logika przedsiębiorstw międzynarodowych, która redukuje człowieka do narzędzia, jest niezgodna $\mathrm{z}$ uniwersalizmem. Dzieje się to przez totalitaryzm zysku. Mundializacja władzy politycznej ma - w przekonaniu lubelskiego uczonego - nadrzędny cel: wymuszenie skutecznego respektowania praw człowieka w globalnej gospodarce ${ }^{26}$.

Pierwszym papieżem, który na gruncie nauczania społecznego Kościoła wyraźnie wskazał na potrzebę powołania tego typu władzy i uszczegółowił swoją sugestię praktycznymi radami, był Jan xxıII. Droga do wyartykułowania postulatu powołania władzy ogólnoświatowej wiodła przez encyklikę Mater et magistra (1961), w której autor wylicza palące problemy współczesnego mu świata: dysproporcje między rolnictwem a przemysłem i sektorem usług, przepaść pomiędzy rozwiniętymi społecznie i gospodarczo mocarstwami a krajami Trzeciego Świata, dysproporcje między liczbą ludności a środkami utrzymania czy też wyścig zbrojeń. Sposobem rozwiązywania tych niepokojących zjawisk ma być dla papieża współpraca wszystkich narodów ${ }^{27}$. Dwa lata później ukazała się kolejna encyklika społeczna tego samego autora, Pacem in terris, w której wprost stwierdza się potrzebę powołania powszechnej władzy publicznej: „A ponieważ obecnie ze wspólnym dobrem wszystkich narodów wiążą się zagadnienia dotyczące wszystkich narodów, i ponieważ zagadnienia te może rozwiązać jedynie jakaś władza publiczna, posiadająca i moc, i organizację, i środki o równie wielkim zasięgu oraz obejmująca zakresem swego działania cały świat - wynika $\mathrm{z}$ tego, że nawet $\mathrm{z}$ nakazu samego porządku moralnego trzeba ustanowić jakąś powszechną władzę publiczną. Ta zaś władza powszechna, której zasięg winien rozciągać się na cały świat i która powinna dysponować

\footnotetext{
${ }^{25}$ F. J. Mazurek, Podstawy moralno-prawne globalizacji gospodarczej, s. 42.

${ }^{26}$ Tamże, s. 45.

${ }^{27}$ MM 122-211.
} 
odpowiednimi środkami, wiodącymi do powszechnego dobra wspólnego, musi być ustanowiona w wyniku zgodnego porozumienia wszystkich narodów, a nie narzucona przemocą. A to dlatego, że jeśli tego rodzaju władza ma spełniać skutecznie swe zadania, to musi odnosić się jednakowo do wszystkich, nie ulegać nigdy stronniczości i mieć na celu wspólne dobro narodów"28. Trzeba tu zaznaczyć, że istotnym kryterium właściwego funkcjonowania tego typu władzy powinno być respektowanie przez nią zasady pomocniczości.

\section{W kierunku „moralności globalnej”}

Jednym z istotnych osiągnięć obecnego rozwoju cywilizacyjnego jest świadomość wspólnego interesu w działaniach na rzecz ochrony środowiska i złóż naturalnych. Problem ten eksploatowany jest wszechstronnie w ramach polityki tzw. zrównoważonego rozwoju (ang. sustainable development, niem. Nachhaltigkeit). Pojęcie zrównoważonego rozwoju ujmowane jest wieloaspektowo. Wiąże się ono z ekorozwojem, trwałym rozwojem umożliwiającym zabezpieczenie złóż naturalnych następnym pokoleniom. Jest to więc rozwój uwzględniający wymogi ekologiczne. W literaturze przedmiotu często przytacza się definicję trwałego rozwoju zawartą w raporcie Nasza wspólna przyszłość (Our common future). Ekorozwój tłumaczy się tu jako rozwój społeczny i gospodarczy, który ma zaspokoić potrzeby współczesnej generacji, bez ryzyka, że przyszłe pokolenia nie będą mogły ich zaspokoić z powodu ich nadmiernej eksploatacji przez pokolenie obecne. Zrównoważony rozwój powinien być uznany za cel polityki wszystkich państw ${ }^{29}$.

Markus Vogt uważa, że do istoty zrównoważonego rozwoju należy planowe, perspektywiczne i rozważne integrowanie gospodarki w ekologiczny cykl surowcowy i dostosowanie jej do czasowego rytmu regeneracji

${ }^{28}$ PT $137-138$.

${ }^{29}$ E. Mazur-Wierzbicka, Miejsce zrównoważonego rozwoju w polskiej i unijnej polityce ekologicznej na początku XxI wieku, „Nierówności społeczne a wzrost gospodarczy. Problemy globalizacji i regionalizacji” 8 (2006), cz. 1, s. 317-318; zob. D. Wortmann, Von der Vision zur Strategie. Grundelemente und Entwicklungsmuster einer Politik der Nachhaltichkeit, w: Sustainable Development - Utopie oder realistische Vision?, Hg. M. Sebaldt, Hamburg 2002, s. 95 . 
surowcó $w^{30}$. Kryzys ekosystemu należy uznać jednak za problem uwarunkowany nie tylko zachwianiem równowagi ekologicznej na skutek niepohamowanej działalności gospodarczej, ale trzeba rozpatrywać go w paradygmacie antropologiczno-etycznym. Kryzys ten jest uwarunkowany przede wszystkim czynnikiem historyczno-filozoficznym, tj. błędnymi koncepcjami człowieka i kosmosu ${ }^{31}$. Na szczególną uwagę zasługuje tu fakt, że Mazurek umiejscawia potrzebę ochrony środowiska w szerszym kontekście prawa człowieka do rozwoju integralnego. Uważa on przy tym, że nadmiernie eksponuje się wzrost gospodarczy jako ten, który miałby służyć rozwojowi człowieka. Ujmowanie rozwoju tylko w kategoriach ilościowych, przy pomijaniu kategorii jakościowych, jest - w jego przekonaniu - błędem. Poszukuje on takiego modelu ekologicznego, który będzie realizowany w ramach nowej cywilizacji - personalistyczno-integralnej ${ }^{32}$. Adekwatną antropologią filozoficzną do rozwiązania kryzysu ekosystemów jest jego zdaniem filozofia personalizmu, w niej bowiem uznaje się godność osoby ludzkiej za najwyższą wartość, a $\mathrm{z}$ tej dopiero odczytuje się prawa i obowiązki człowieka, w tym także prawo do zdrowego i zrównoważonego środowiska ${ }^{33}$ oraz obowiązek troski o nie.

Do szeroko pojętej współczesnej kwestii społecznej zalicza się takie zjawiska, jak zanieczyszczenie naturalnego środowiska, egoistyczne dążenie państw uprzemysłowionych i korporacji międzynarodowych do wykorzystywania zasobów ziemi, w tym dna morza, oraz egoistyczne chronienie nowych technologii. Na tle tych negatywnych zjawisk da się zauważyć wzrastającą świadomość praw trzeciej generacji, nazywanych prawami solidarnościowymi. Racją przemawiającą za ich przywołaniem w tym miejscu jest choćby fakt, że mogą być one urzeczywistniane jedynie na drodze współpracy międzynarodowej. Należy wymienić tu choćby

${ }^{30}$ M. Vogt, Prinzip Nachhaltigkeit. Ein Entworf aus theologisch-ethischer Perspektive, München 2009, s. 135.

${ }^{31}$ F. J. Mazurek, Prawo człowieka do zdrowego (czystego) i zrównoważonego środowiska, w: Dzieje gospodarcze. Współczesność. Zamojszczyzna. Prace ofiarowane Profesorowi Ryszardowi Orłowskiemu w pięćdziesięciolecie pracy naukowej, red. W. Ćwik, Z. Szymański, Zamość 2002, s. 252; zob. tenże, Założenia nowego ładu gospodarki światowej, „Roczniki Nauk Społecznych" 6 (1978), s. 215-232.

${ }^{32}$ Tenże, Prawo człowieka do zdrowego (czystego) i zrównoważonego środowiska, s. 251.

${ }_{33}$ Tamże, s. 271. 
prawo do rozwoju, prawo do życia w pokoju, prawo do powszechnego używania dóbr ziemskich (prawo do dziedzictwa rodzaju ludzkiego) oraz prawo do życia w nieskażonym środowisku.

Karel Vasak zalicza prawo człowieka do zdrowego środowiska naturalnego do praw solidarnościowych (trzeciej generacji). Podaje on przy tym następujące jego brzmienie: „Każdy człowiek i wszyscy ludzie ujęci zespołowo mają prawo do zdrowego środowiska i ekologicznie zrównoważonego, właściwego dla ich rozwoju zarówno ekonomicznego, jak i społecznego, kulturalnego, politycznego i prawnego" ${ }^{34}$. Z tak sformułowanego prawa wynikają następujące imperatywy: władza państwowa powinna stać na straży zdrowia człowieka, nie pozwalać na wprowadzanie do naturalnych warunków niekorzystnych zmiana dla życia ludzkiego; powinna umożliwić obywatelom wnoszenie skarg z tytułu takiego niebezpieczeństwa, a w przypadku poniesienia szkody winna zapewnić prawo do odszkodowania zgodnie z ustawą narodową ${ }^{35}$.

Wciąż brak wspólnego stanowiska uczonych co do charakteru i podstawy prawa do zdrowego środowiska naturalnego. Mazurek uważa, że podstawą wszystkich praw - również solidarnościowych, a wśród nich omawianego - jest godność osoby ludzkiej ${ }^{36}$. Pogląd ten jest integralną częścią zarysowanej wyżej jego koncepcji ekologicznej, w której traktuje się ochronę środowiska nie za cel sam w sobie, ale za warunek kształtowania właściwego środowiska rozwoju człowieka i promowania jego godności. W dziedzinie tej wiele zależy od współpracy międzynarodowej i przyjętej polityki w skali globalnej. Nawiązując do pojęć autorstwa

${ }^{34}$ Cyt. za: tamże, s. 257.

35 Tamże. Zob. tenże, Prawo człowieka do zdrowego środowiska, „Człowiek i Przyroda” 15-16 (2002-2003), s. 141-156.

${ }^{36}$ Ksiądz Franciszek Mazurek pisze: „Odczytywane zaś z wrodzonej i niezbywalnej godności osoby ludzkiej wszystkie prawa człowieka, zanim zostaną proklamowane w konwencjach międzynarodowych czy konstytucjach państw, mają jedynie charakter moralny. Chodzi tu także o prawa człowieka trzeciej generacji - prawa solidarnościowe, które nie zostały jak dotąd proklamowane w powszechnej konwencji międzynarodowej” (tenże, Godność osoby ludzkiej podstawa praw człowieka, Lublin 2001, s. 418). 
Jana Dębowskiego: „moralność globalna” (etyka globalna) i „etyka ekologiczna" ${ }^{37}$, niemal naturalnie nasuwa się konkluzja: sprawa ochrony środowiska naturalnego nie jest jedynie problemem ekologicznym, gospodarczym, politycznym czy prawnym, ale również pedagogicznym. Skoro u podstaw tej ochrony leży integralny obraz osoby ludzkiej oraz jej godność, jest to też problem filozoficzny i moralny.

\section{Bibliografia}

Dębowski J., Etyczne aspekty międzynarodowej wspólpracy ekologicznej, w: Ekologia społeczna i wspótpraca międzynarodowa w zakresie ochrony środowiska, red. E. J. Pałyga, Fundacja im. Andrzeja Frycza Modrzewskiego, Warszawa 1992, s. 25-46.

Fel S., Kupny J., Humanizacja życia gospodarczego. Wybrane zagadnienia z etyki gospodarczej, przedm. F. J. Mazurek, Polihymnia, Lublin 2000.

Fel S., Oswalda von Nell-Breuninga koncepcja ładu społeczno-gospodarczego, Wydawnictwo KUL, Lublin 2007.

Jan Paweł II, Encyklika Centesimus annus, przedruk: Libreria Editrice Vaticana, Włocławek 1991.

Jan XXII, Encyklika Mater et magistra, Société d'Éditions Internationales, Paris 1963.

Jan xxII, Encyklika Pacem in terris, Katolicki Ośrodek Wydawniczy „Veritas”, London 1963.

Komisja „Iustitia et Pax” Episkopatu Francji, O właściwy kształt mundializacji, w: Kościół wobec współczesnych problemów życia gospodarczego. Społeczne dokumenty episkopatów, red. S. Fel, J. Kupny, Wydawnictwo KUL, Lublin 2002, s. 305-327.

Luhmann N., Teoria polityczna państwa bezpieczeństwa socjalnego, tłum. i wstęp G. Skąpska, Wydawnictwo Naukowe Pwn, Warszawa 1994.

Mazurek F. J., Godność osoby ludzkiej jako norma, „Społeczeństwo. Studia. Prace badawcze. Dokumenty z zakresu nauki społecznej Kościoła” 4 (1995), s. $753-776$.

${ }^{37}$ Tenże, Prawo człowieka do zdrowego (czystego) i zrównoważonego rozwoju, s. 252. Zob. J. Dębowski, Etyczne aspekty międzynarodowej wspótpracy ekologicznej, w: Ekologia społeczna $i$ wspótpraca międzynarodowa w zakresie ochrony środowiska, red. E. J. Pałyga, Warszawa 1992, s. 25-46. 
Mazurek F. J., Godność osoby ludzkiej podstawa praw człowieka, Redakcja Wydawnictw KUL, Lublin 2001.

Mazurek F. J., Integralne rozumienie praw człowieka podstawa personalistycznego porzadku społecznego, „Zeszyty Naukowe KUL” 39 (1996), nr 1-2, s. 51-73.

Mazurek F. J., Katolicka nauka społeczna - status metodologiczny i główne obszary problemowe, w: Katolicka nauka społeczna. Podstawowe zagadnienia $z \dot{z} y$ cia społecznego i politycznego, red. S. Fel, J. Kupny, Księgarnia św. Jacka, Katowice 2007, s. 11-30.

Mazurek F. J., Kryteria aksjologiczno-personalistycznej oceny wykluczeń $w$ różnych dziedzinach i wymiarach, w: Kultura. Media. Społeczeństwo. Ksiega Jubileuszowa ku czci Ojca Profesora Leona Dyczewskiego ofmconv, red. D. Wadowski, Wydawnictwo KUL, Lublin 2007, s. 633-646.

Mazurek F. J., Podstawy moralno-prawne globalizacji gospodarczej, w: Państwo narodowe a proces globalizacji, red. E. Okoń-Horodyńska, Wydawnictwo Uczelniane AE, Kraków 2000, s. 19-47.

Mazurek F. J., Prawo człowieka do zdrowego (czystego) i zrównoważonego środowiska, w: Dzieje gospodarcze. Współczesność. Zamojszczyzna. Prace ofiarowane Profesorowi Ryszardowi Orłowskiemu w pięćdziesięciolecie pracy naukowej, red. W. Ćwik, Z. Szymański, Wyższa Szkoła Zarządzania i Administracji. Centrum Badawczo-Szkoleniowe, Zamość 2002, s. 245-271.

Mazurek F. J., Prawo człowieka do zdrowego środowiska, „Człowiek i Przyroda” 15-16 (2002-2003), s. 141-156.

Mazurek F. J., Prawo do rozwoju, „Roczniki Nauk Społecznych” 11 (1983), s. 215262.

Mazurek F. J., Prawo naturalne podstawą stosunków społecznych, „Roczniki Filozoficzne" 21 (1973), z. 2, s. 49-6o.

Mazurek F. J., Problem sprawiedliwości międzynarodowej, „Roczniki Nauk Społecznych" 4 (1976), s. 19-40.

Mazurek F. J., Wartości akceptowane w Unii Europejskiej, „Summarium” 28-29 (1999-200o), s. 5-33.

Mazurek F. J., Wolność i równość społeczna, „Roczniki Nauk Społecznych” 9 (1981), s. 215-251.

Mazurek F. J., Założenia nowego ładu gospodarki światowej, „Roczniki Nauk Społecznych" 6 (1978), s. 215-232.

Mazur-Wierzbicka E., Miejsce zrównoważonego rozwoju w polskiej i unijnej polityce ekologicznej na początku XXI wieku, „Nierówności społeczne a wzrost gospodarczy. Problemy globalizacji i regionalizacji” 8 (2006), cz. 1, s. 317-328. 
Müller-Armack A., Genealogie der Sozialen Marktwirtschaft. Frühschriften und weiterführende Konzepte. Sozioökonomische Forschungen, t. 1, Bern Paul Haupt Verlag, Bern-Stuttgart 1974.

Nass E., Państwo prawa i państwo socjalne w ujęciu chrześcijańskim, w: Katolicka nauka społeczna. Podstawowe zagadnienia z życia społecznego i politycznego, red. S. Fel, J. Kupny, Księgarnia św. Jacka, Katowice 2007, s. 146-168.

Novak M., Liberalizm - sprzymierzeniec czy wróg Kościoła. Nauczanie społeczne Kościoła a instytucje liberalne, tłum. W. Büchner, W Drodze, Poznań 1993.

Papieska Rada „Iustitia et Pax”, Kompendium nauki społecznej Kościoła, Jedność, Kielce 2005.

Vogt M., Prinzip Nachhaltigkeit. Ein Entworf aus theologisch-ethischer Perspektive, Oekon Verlag, München 2009.

Wortmann D., Von der Vision zur Strategie. Grundelemente und Entwicklungsmuster einer Politik der Nachhaltichkeit, w: Sustainable Development - Utopie oder realistische Vision?, Hg. M. Sebaldt, Verlag Kovac, Hamburg 2002.

\section{Abstrakt}

Przedmiotem niniejszego artykułu są uniwersalne normy, zasady i wartości nieodzowne dla polityki wykraczającej poza granice państw narodowych. Podjęto w nim próbę rekonstrukcji aksjologicznych podstaw ładu politycznego niezbędnych do budowania dobra wspólnego w wymiarze globalnym. Omówiono następujące zagadnienia: kryterium antropologiczne w ocenie zjawisk mundializacji, postulat demokracji integralnej i jej znaczenie dla polityki państw narodowych, rolę zrównoważonego rozwoju w ekologii integralnej oraz znaczenie moralności w społecznych, gospodarczych i kulturalnych procesach globalizacji.

Axiological foundations of political order in the days of globalization

\section{Abstract}

The topic of this paper is the universal norms, principles and values, necessary for the politics to cross the borders of national states. Axiological foundations of political order are reconstructed, those vital for the common good to be built on the global level. The following problems are discussed: antropological 
criteria for evaluation of the phenomena of mundialization, the idea of integral democracy and its value for the politics in national states, the place of the sustainable development in the integral ecology as well as the call for morality in social, economical, and cultural processes of globalization. 